\title{
LYUBEN KARAVELOV: THE BULGARIAN NARRATOR, JOURNALIST AND REVOLUTIONARY ${ }^{1}$
}

\section{Abstract:}

The article is about Lyuben Karavelov (1834-79), the preeminent Bulgarian writer who worked in the era of the Bulgarian national revival, an author of tales, short stories, ethnographic essays and political articles. Almost all of his creative life was spent in exile: he lived in Russia, the Serbian Principality, Austria-Hungary and Romania and published his works not only in Bulgarian, but also in Russian and Serbian, influencing the development of literary movements wherever he was located. In his creative evolution, he moved towards a realistic representation of life, overcoming the tendency typical of Bulgarian writers at that time to write with elements of sentimentalism and revolutionary romanticism. He wrote the best Bulgarian story of that era, "Bulgarians of Old times". Many of his works reflected the influence of N.V. Gogol, N.G. Chernyshevsky and M. Vovchok, and contributed to the formation of realism not only in Bulgarian but also in Serbian literature. His influence would have been much greater if he had not died at the age of 45 from tuberculosis immediately after the liberation of Bulgaria from the Ottoman yoke.

\section{Keywords:}

Bulgarian national revival, Bulgarian literature, Lyuben Karavelov, emigration, the best national fiction writer of his time, affirmation of realism.

АННОТАЦИЯ: М.Г. СМОЛЬЯНИНОВА. «БОЛГАРСКИЙ ПРОЗАИК, ЖУРНАЛИСТ И РЕВОЛЮЦИОНЕР ЛЮБЕН КАРАВЕЛОВ».

В статье речь идет о Любене Каравелове (1834-79) - крупнейшем болгарском писателе, творившем в эпоху Болгарского национального возрождения, авторе повестей, рассказов, этнографических очерков и политико-публицистических статей. Почти вся его творческая жизнь прошла в эмиграции: он жил в России, Сербском княжестве, Австро-Венгрии и Румынии и публиковал свои произведения не только на болгарском, но и на русском и сербском языках, оказывая воздействие на развитие литературных процессов там, где он находился. В своей творческой эволюции он двигался к реалистическому изображению действительности, преодолевая тогдашнее увлечение болгарских писателей сентиментализмом и революционным романтизмом. Ему принадлежит лучшая болгарская повесть той эпохи - «Болгары старого времени». Во многих его произведениях отразилось влияние Н.В. Гоголя, Н.Г. Чернышевского и М. Вовчок, он способствовал становлению реализма не только болгарской, но и сербской литературы. Масштабность его фигуры была бы гораздо больше, не умри он в возрасте 45 лет от туберкулеза сразу же после освобождения Болгарии от османского ига.

\section{Ключевые слова:}

Национальное болгарское возрождение, болгарская литература, Любен Каравелов, эмиграция, лучший национальный беллетрист своего времени, утверждение реализма.

\footnotetext{
1 The work was carried out with the financial support of the RFBR (grant № 18-512-76004).
} 


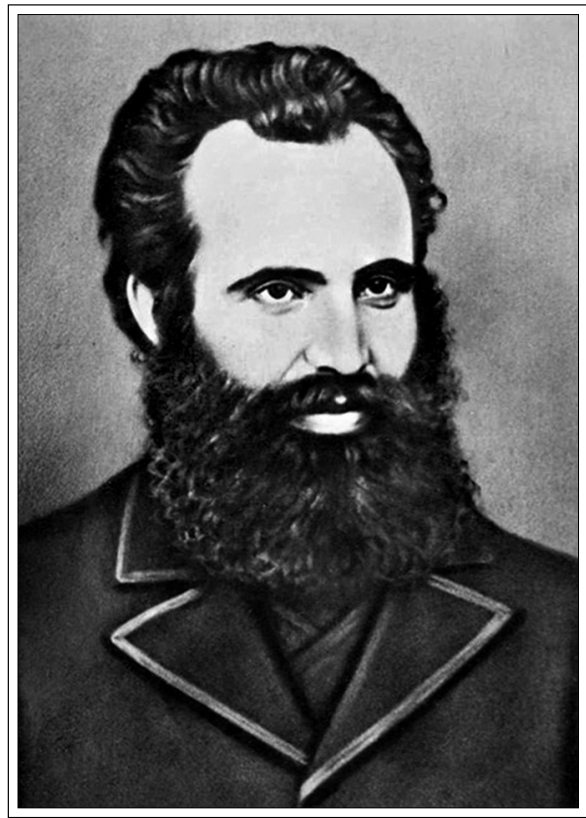

Lyuben Karavelov.

Photographer

Anastas Nikolov Stoyanovich, 1876
Tyuben Karavelov was a Bulgarian writer of prose, poet, playwright, publicist, literary critic, folklorist. He studied in Koprivshtitsa and Plovdiv at a Greek gymnasium and at a Bulgarian school. In 1857 he arrived in Moscow, where he spent 10 years. The following year Karavelov became a volunteer at the Historical and Philological faculty of Moscow University. He received a five-year scholarship from the Slavic Charity Committee and until 1864 he attended the lectures of O.M. Bodyansky on "Slavic dialects," S.M. Soloviev on Russian history, S.V. Yeshevsky on world history and other famous professors at the university. During this time he became close to Slavophiles and Slavic scholars M.P. Pogodin, V.I. Lamansky, A.N. Afanasyev, N.A. Popov, and read the works of Gogol, Dostoevsky, Shevchenko, Chernyshevsky, Pisarev and Belinsky. At the same time Karavelov was attending meetings of banned revolutionary circles, for which he was subjected to police surveillance. One can say that as a writer he was formed in Russia.

Karavelov published his first poems, translations, and critical articles in 1860 in the journal Bratsky trud ("The Brotherly Work"): an arm of the Moscow Bulgarian "squad," which brought together his fellow Bulgarians studying in Moscow. His first short story, Ataman (from the Bulgarian customs), was written in Russian and was published in 1860 in the Russian newspaper Nashe vremya ("Our Time"). Karavelov next published a collection, Monuments of the Folk Life of the Bulgarians, which included fairy tales, proverbs and sayings, described folk rites and customs. He combined all of his tales and short stories published in the Russian periodical in the collection Pages from the book of the Bulgarian tribe suffering (Moscow, 1868). In his prose, Karavelov was influenced by Russian and Ukrainian literature, especially that of Gogol, Chernyshevsky, and Vovchok. If sentimental tendencies can be felt in the works relating the sufferings of his compatriots [Siroto semeistvo ("The Orphaned Family"), "Neda", Na chuzhd grob bez sâlzi plachat ("On a nonrelative's grave one cries without tears"), and the rebel tales about the fighters's heroism against the enslavers are romantic in nature ("Voivode", "Doncho", "Martyr")], then the novel Balgari ot staro vreme ("Bulgarians of Old times") displayed the writer's skill in writing realism. In it 
the author described life and social relations in Bulgaria in the mid-19th century, using the example of his native Koprivshtitsa. The prototype of one of its main characters was the writer's grandfather, and some of its characters bear the actual names of their prototypes. However, this did not mean that he portrayed reality similar to a documentary. Learning from Gogol, in his early stories Karavelov used some of Gogol's artistic techniques. This included stylized folk speech, and the use of Bulgarian words and expressions explained by the author in the Russian text, as well as his use of introductory episodes that tell about the narrator, and humor in describing the characters. However, after copying certain techniques, the Bulgarian writer quickly moved on to the development of a realistic type of creativity. His skill was manifested both in the accurate depiction of everyday details of Bulgarian life, and in sparkling humor and subtle irony in depicting typical national characters (above all, the images of Hadzhi Gencho and grandfather Liben, who have become household names among the Bulgarians). The story is replete with folkloric comparisons, proverbs and sayings that are organically woven into its artistic fabric.

Karavelov was a multilingual writer: he wrote not only in Bulgarian and Russian, but also in Serbian, achieving not only great artistry, but his works also had an influence on the literary process of the country in which he created. In 1867, while in Serbia as a correspondent for Russian newspapers, he wrote and published three novellas in the Serbian language:Je li kriva sudbina? ("Is fate too blame?") in 1868, and a year later - Nakazao je bog ("God punished her") and Gorka sudbina ("Bitter Fate"). While Karavelov's works of fiction in Russian recounted Bulgarian reality, his Serbian cycle reflected Serbian reality, and he was thus actively involved in the development of realism in Serbian literature. In one story that was extremely popular among Serbian readers, "Is fate too blame?," the writer showed the cruelty of the Serbian principality's corrupt elite and at the same time created images of forward-thinking people of a new type in the spirit of the heroes of Chernyshevsky's novel "What Is to Be Done?" In Serbia Karavelov was a kind of conduit for the influence of Russian literature. His critical articles on Serbian literature (Poetry and Thought, How we were brought up) were evaluated by the Serbian democrat $S$. Markovich as the beginning of a critical attitude in Serbia towards an idealistic and romantic worldview. For his sharp criticism of the Belgrade rulers, Karavelov was first expelled from the country to Novi Sad in Austria-Hungary, and then in 1868 he was imprisoned in a Pest jail on false charges. After his release, Karavelov, under the influence of Dostoevsky's "Notes from the Underground," wrote his memoirs, Iz mârtviya dom ("From the Dead House"), describing his sufferings during his own imprisonment (1869).

Having moved to Bucharest, then the center of Bulgarian emigration, the writer began to publish the Bulgarian newspaper Svoboda ("Freedom," 1869-72) and its continuation, Nezavisimost ("Independence," 1873-74). Their main task was to prepare a revolution in Bulgaria. In these publications Karavelov published pointed pamphlets, feuilletons, as well as new literary and critical articles, 
prose and poetry: "Hadzhi Nicho," (1870), Bogatiyat siromakh ("The Rich Pauper," 1872), the trilogy Otmshchenie ("Vengeance"), Posle otmshchenia ("After the revenge"), and Tuka mu e krayat ("Here he is finished," 1872-74), as well as stories written in Russia and Serbia in a significantly revised and expanded form.

Shocked by the tragic death of Vasil Levski, Karavelov doubted the possibility of achieving freedom through revolution. He ceased publishing the newspaper Nezavisimost ("The Independence"), left the leadership of the revolutionary body and in 1875 began to publish the journal Znanie ("Knowledge"), promoting educational ideas in it. Under the general heading Tri kartini iz bâlgarskiya zhvot ("Three pictures from Bulgarian life"), he published the novellas Mamino detentse ("Mama's boy"), Izvânreden rodolyubets ("Unusual Patriot") and Progressist ("Fantastically progressive man") - bright satirical works, attesting to their author's loyalty to democratic positions. During the Russo-Turkish War of 1877-78, Karavelov worked as a translator in the Russian army. In the summer of 1878, after the liberation of Bulgaria from the five-century-long Ottoman yoke, he returned to his homeland, and thus his wandering odyssey finally came to an end. The circle "Bulgaria - Russia - Serbia - Austria-Hungary - Romania - Bulgaria" had closed. However, the writer did not have long to inhale the smells of his native land: only six months later, in January 1879, he died of tuberculosis at the age of 45 and was buried in Ruse. However, he died not in a foreign

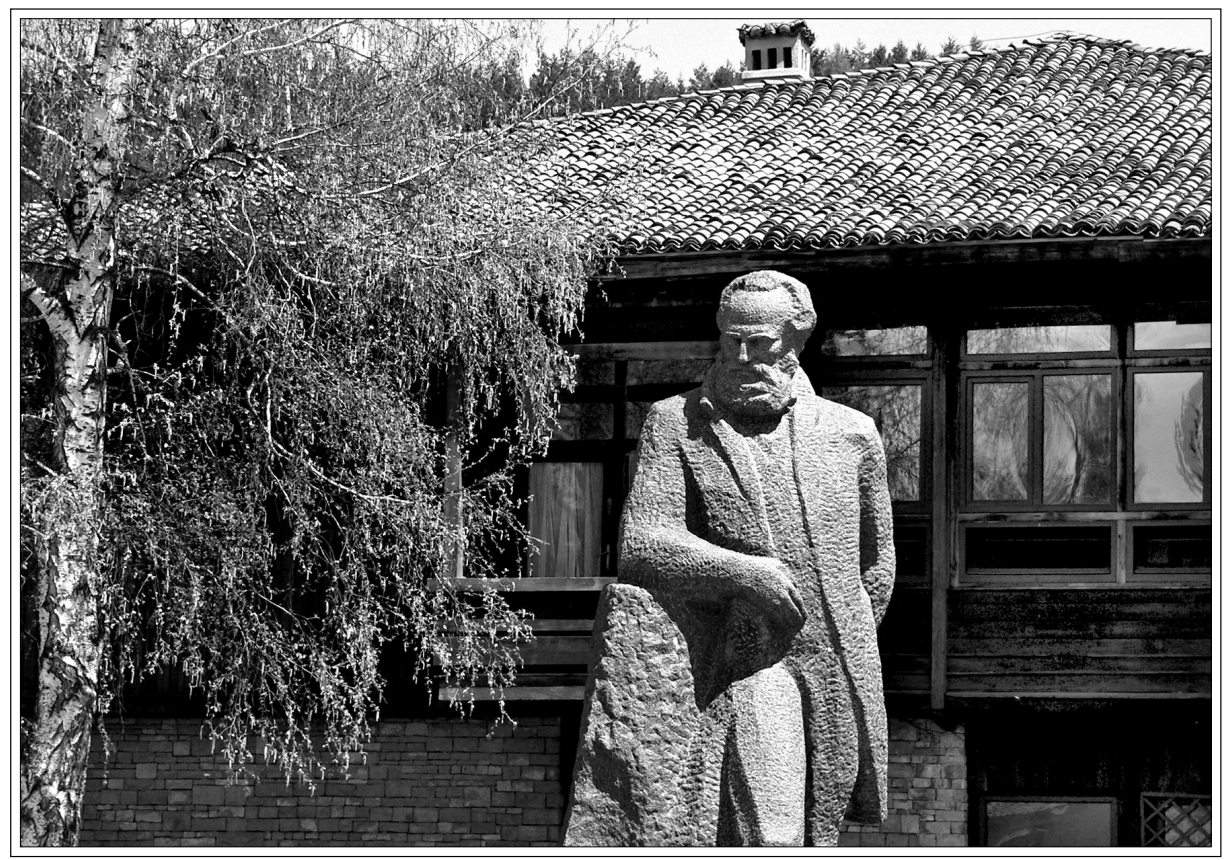

Monument to Lyuben Karavelov in Koprivshtitsa near his house. Sculptor Nadezhda Petrenko 
land, but in his own native land, as he himself had wished. While in exile, Lyuben Karavelov wrote the poem Khubava si moya goro ("You are beautiful, dear forest"). His beautiful but enslaved homeland appeared to him in the form of a spring forest, as an embodiment, characteristic of "Hayduk" epics. This elegy of his reflected the longing of numerous Bulgarian exiles for their lost homeland; it became one of the most popular folk songs and an eternal hymn of love for the native land. No matter where his fate as an emigrant cast him, Karavelov's thoughts were always turned toward Bulgaria. He enthralled his compatriots with the ideals of freedom and worked toward realising them with all his public activities and artistic creativity.

Translated by Igor Kaliganov

\section{BIBLIOGRAPHY}

Karavelov Lyuben. Sabrani sachinenia. T. 1-12. Sofia, 1984-1989.

Lekov D. Lyuben Karavelov. Plovdiv, 1998.

Likhacheva L.P. Lyuben Karavelov: Biobibliograficheskii ukazatel'. Moskva, 1954.

Lyuben Karavelov. Bolgary starogo vremeni: Izbrannye proizvedenia. Perevod s bolgarskogo i serbskogo. Moskva, 2002.

Svetozar Markovič i Lyuben Karavelov u kontekstu slovenske književnosti i kulture : zbornik radova. Beograd, 1992.

Vorob'ev L.V. Lyuben Karavelov. Moskva, 1980.

\section{ILLUSTRATIONS}

1. Lyuben Karavelov. Photo of the writer, until 1879.

2. Lyuben Karavelov. Photographer Anastas Nikolov Stoyanovich, 1876.

3. The book by L. Karavelov "Mama's boy." Sofia, 1946.

4. The story by Lyuben Karavelov "Bulgarians of Old time" in Russian translation. Moscow, 1977.

5. Monument to Lyuben Karavelov in Koprivshtitsa near his house. Sculptor Nadezhda Petrenko.

6. The House Museum of Lyuben Karavelov in Koprivshtitsa.

7. The house in Bucharest where Lyuben Karavelov lived and worked.

8. The Library. "Lyuben Karavelov" in Ruse.

9. The Grave of Lyuben Karavelov in Ruse.

10. The ship "Lyuben Karavelov." 